\title{
Zooplankton response to organic carbon level in lakes of differing trophic states
}

\author{
M. Bowszys ${ }^{(1), \star}$, J.A. Dunalska ${ }^{(2)}$, B. Jaworska ${ }^{(3)}$ \\ Received June 14, 2013
}

Revised December 12, 2013

Accepted December 13, 2013

Key-words:
zooplankton,
Crustacea,
total organic
carbon,
dissolved
organic carbon,
particulate
organic carbon

\section{ABSTRACT}

Water eutrophication is associated with an increase in the organic carbon content (both particulate and dissolved forms), which may affect the functioning of the zooplankton community. Mesotrophic and eutrophic lakes in the Masurian Lake District (Poland) were selected to evaluate the relationship between the organic carbon level and the zooplankton community. The lakes differed significantly in most environmental variables. RDA analysis was performed to evaluate the impact of environmental variables on zooplankton. The variables that significantly explained the variance in the zooplankton community abundance (Monte Carlo permutation test) included dissolved and particulate organic carbon, Secchi disc visibility, soluble reactive phosphorus and total nitrogen. The response of zooplankton to an increasing level of organic carbon is functional rather than quantitative. In the mesotrophic system, the results of the redundancy analysis indicated relatively strong positive relationships between dissolved organic carbon and zooplankton biomass, and negative correlations between chlorophyll $a$ and zooplankton biomass. The above suggests that indirect organic carbon utilization by zooplankton could partly compensate for the poor feeding conditions of planktonic animals (decreased phytoplankton availability). In the eutrophic lake, elevated organic carbon levels are partly limited by zooplankton, which is suggested by the positive relationship between particulate organic matter and the total zooplankton biomass (RDA results). The positive relationship between the biomass of copepods and organic carbon in particulate and dissolved forms implies that copepods benefit from the increased heterotrophic carbon flow that is activated in the eutrophic lake.

\section{RÉSUMÉ}

Réponse du zooplancton au niveau de carbone organique dans des lacs de statuts trophiques différents

Mots-clés : zooplancton, crustacés,
L'eutrophisation de l'eau est associée à une augmentation de la teneur en carbone organique (à la fois les formes particulaires et les dissoutes), ce qui peut affecter le fonctionnement de la communauté du zooplancton. Des lacs mésotrophes et eutrophes dans le district des lacs de Mazurie (Pologne) ont été choisis pour évaluer les relations entre le niveau de carbone organique et la communauté

(1) Department of Applied Ecology, University of Warmia and Mazury, Oczapowskiego 5, 10-957 Olsztyn, Poland (2) Department of Water Protection Engineering, University of Warmia and Mazury, Prawocheńskiego 1, 10-957 Olsztyn, Poland

(3) Department of Applied Ecology, University of Warmia and Mazury, Oczapowskiego 5, 10-957 Olsztyn, Poland

^Corresponding author: mbowszys@uwm.edu.pl 
carbone organique total, carbone organique dissous, carbone organique particulaire du zooplancton. Les lacs diffèrent significativement dans la plupart des variables environnementales. L'analyse RDA a été réalisée pour évaluer l'impact des variables environnementales sur le zooplancton. Les variables qui expliquent de façon significative la variance de l'abondance de la communauté de zooplancton (test de permutation de Monte Carlo) comprennent le carbone organique dissous et particulaire, la visibilité du disque de Secchi, le phosphore réactif soluble et l'azote total. La réponse du zooplancton à l'augmentation du niveau de carbone organique est fonctionnelle plutôt que quantitative. Dans le système mésotrophe, les résultats de l'analyse de redondance indiquent de relativement fortes relations positives entre le carbone organique dissous et la biomasse de zooplancton et des corrélations négatives entre la chlorophylle a et la biomasse de zooplancton. Ce qui précède suggère que l'utilisation indirecte du carbone organique par le zooplancton pourrait compenser en partie les mauvaises conditions d'alimentation des animaux planctoniques (diminution de la disponibilité du phytoplancton). Dans le lac eutrophe, les niveaux élevés de carbone organique sont en partie limités par le zooplancton ce qui est suggéré par la relation positive entre la matière organique particulaire et la biomasse totale de zooplancton (résultats RDA). La relation positive entre la biomasse des copépodes et les formes dissoutes et particulaires du carbone organique signifie que les copépodes bénéficient de l'augmentation du flux de carbone hétérotrophe activée dans le lac eutrophe.

\section{INTRODUCTION}

Eutrophication and related increases in the productivity of lakes are closely associated with the content of organic carbon in water. An increase in the fertility of lakes results in increased levels of both particulate and dissolved forms of organic matter (Dunalska, 2011; Dunalska et al., 2012). Increasing primary and secondary production together with the remains of aquatic organisms supply the pool of particulate organic carbon (POC) in a water body. The dissolved organic carbon (DOC) content in water increases because of the microbiological degradation of organic matter produced in the lake, but mainly because of its release by aquatic organisms, i.e., algal exudation, the lysis of phytoplankton cells, and direct and indirect release by zooplankton and other aquatic animals (Wetzel, 1983; Hoppe, 1984).

Apart from autochthonous sources, both forms of organic matter also originate from watersheds as labile and refractory compounds (Fukushima et al., 1996). Allochthonous sources of organic matter may significantly fuel the pelagic food web, but seasonal variability exists in terrestrial carbon subsidies (Tranvik, 1992; Grey et al., 2001). However, lakes whose functioning is based exclusively on allochthonous matter disrupt the paradigm of a classical food web (Reynolds, 2008). The metabolism of such lakes is heterotrophic and based on the influx of DOC from the drainage basin and its subsequent transformations by microorganisms (Azam et al., 1983). The opposite situation takes place in lakes exhibiting an autotrophic metabolism, where gross primary production dominates over system respiration (Cole et al., 2000; Hanson et al., 2003).

Dissolved organic carbon is closely correlated with communities and directly or indirectly influences aquatic organisms and their habitats. Numerous studies have demonstrated a positive correlation between bacteria abundance and DOC concentration; DOC constitutes an alternative source of carbon and energy for zooplankton (Azam et al., 1983; Jansson et al., 1999; Chróst and Siuda, 2006; Hitchcock et al., 2010). On the other hand, by affecting water color, increasing concentrations of DOC in lake water may limit the extent of the euphotic zone and primary production rate, even though DOC is subject to partial photodegradation under sunlight (Perez-Fuentetaja et al., 1999; de Lange et al., 2003). Phytoplankton production dominates when DOC levels do not exceed $10 \mathrm{mg} \cdot \mathrm{L}^{-1}$ (Jansson et al., 2000). Further increases in DOC concentrations may cause bacterial production to exceed autotrophic production. The role of the primary carbon assimilation pathway by which its organic form is transferred by grazing to higher trophic levels then decreases. Therefore, bacteria and phytoplankton are 
important links by which organic carbon is transferred into higher trophic levels (Cole et al., 2002; Karlsson et al., 2003).

The zooplankton community acts as a module that combines both alternative carbon cycles in water. This community benefits from both the autotrophic and heterotrophic pathways and plays a regulatory role. The trophic activity of zooplankton may contribute to the elimination of POC (planktonic organisms and detritus) from the water. By feeding, herbivorous organisms limit the growth of phytoplankton and may affect the extent of algal exudation. Detritivores consume dead matter with detritus-attached bacteria and thereby contribute to nutrient recycling. Products of the metabolic activity of planktonic animals are excreted as DOC, mainly in a labile form but also in a refractory form (Park et al., 1997). Some studies have also indicated that zooplankton are capable of the direct utilization of DOC (Salonen and Hammar, 1986).

On the other hand, the organic carbon content in lake water, especially DOC, may indirectly affect the zooplankton community by regulating the depth of ultraviolet radiation (UV) penetration, but this effect is limited. UV radiation may influence the distribution and migration of aquatic animals but usually has no impact on community biomass (Leech et al., 2005; Häder et al,. 2007). In freshwater ecosystems, the effect of UV on zooplankton is only expected in lakes with low DOC (Clair et al., 2001; Leech et al., 2005). An exponential increase in UV penetration in the vertical profile is recorded at DOC concentrations of less than $2 \mathrm{mg} \cdot \mathrm{L}^{-1}$ (Häder et al., 2007).

Some of the most recent studies associate the transformations of organic matter with the trophic state of lakes. A very strong positive correlation has been detected between trophic state indices (TSI), which describe the state of a lake and the concentration of DOC, the production of organic matter, the primary production of phytoplankton and the excretion of organic carbon by phytoplankton. In addition, the intensity of microbiological processes associated with the production and utilization of organic matter closely correlates with the degree of eutrophication in lakes (Chróst and Siuda, 2006). Responses of subsequent trophic levels are thus expected, as has been suggested by other studies showing that increases in nutrient availability evoke a reaction from organisms suspended in the water column, thereby influencing carbon flux in this part of the ecosystem (Olsen et al., 2007). Depending on the level of nutrients, the addition of DOC into the environment stimulates planktonic bacteria or phytoplankton and thus alters the response of zooplankton (Hitchcock et al., 2010). Limited attempts have been made to relate the zooplankton community to the organic matter content in lakes along a trophic gradient. With comparable levels of external supply, it is assumed that an increase in the trophic state of a lake should result in a higher internal DOC supply and an increase in total organic carbon (TOC), which should in turn induce a different response in the zooplankton. In this study, we examined the relationship between zooplankton and various forms of organic carbon content in two lakes of differing trophic state. We hypothesized that in a eutrophic lake, zooplankton should benefit from both an increased DOC level and an abundance of POC as potential food sources. In a mesotrophic lake, an autotrophic pathway of carbon flow based on zooplankton grazing on phytoplankton should play an important role. This attempt may be useful in understanding the role of zooplankton in carbon flow in lakes regarding the process of their eutrophication and related activities aimed at water quality management or lake protection.

\section{MATERIAL AND METHODS}

\section{$>$ THE STUDIED LAKES}

The lakes selected in this study belong to the system of the Great Masurian Lakes located in northeastern Poland (the Masurian Lake District). The basic morphometric parameters of the two studied lakes are shown in Table la. The lakes are through-flow (data on the flushing rate are not available). Both lakes have watersheds with predominantly natural (forests) and semi-natural areas. Forests and grasslands dominate in the close vicinity of the lakes. Due to the location of these lakes within the same lake district system and the similar origin 


\section{Table I}

Basic morphometric and catchments characteristics of Lake Majcz Wielki (MW) and Lake Mikołajskie (M), land use (a), catchments impact and trophic state of the lakes (b).

\begin{tabular}{|c|c|c|}
\hline (a) & MW & M \\
\hline Surface area $\left[\mathrm{km}^{2}\right]$ & 1.63 & 4.97 \\
\hline Maximum depth [m] & 16.4 & 25.9 \\
\hline Lake volume [thousand $\mathrm{m}^{3}$ ] & $9,862.8$ & $5,739.7$ \\
\hline Direct watershed area $\left[\mathrm{km}^{2}\right]$ & 1.18 & 2.32 \\
\hline Land use in the vicinity of lakes [\%]: & & \\
\hline forests & 70 & 43 \\
\hline grasslands & 20 & 27 \\
\hline anthropogenic area & 10 & 19 \\
\hline barrens & - & 11 \\
\hline \multicolumn{3}{|l|}{ (b) } \\
\hline \multicolumn{3}{|l|}{$\begin{array}{l}\text { Indices and corresponding lake susceptibility } \\
\text { to the catchments impact (category): }\end{array}$} \\
\hline average depth $[\mathrm{m}]$ & $6.0\left(1 I^{\star}\right)$ & $11.2(\mathrm{l})$ \\
\hline lake volume/shoreline length & 1.26 (III) & 3.8 (II) \\
\hline \multicolumn{3}{|l|}{ [thousand $\mathrm{m}^{3} \cdot \mathrm{m}^{-1}$ ] } \\
\hline$\%$ lake stratification & 6.5 (IV) & 17 (III) \\
\hline $\begin{array}{l}\text { epilimnion bottom area/epilimnion volume } \\
{\left[\mathrm{m}^{2} \cdot \mathrm{m}^{-3}\right]}\end{array}$ & 0.11 (II) & $0.05(I)$ \\
\hline catchment area/lake volume & $1.0(l)$ & 32.3(III) \\
\hline final category ${ }^{\star \star}$ & II & II \\
\hline Trophic state index ${ }^{\star \star \star}$ & MW & M \\
\hline TSI SD & 43 & 54 \\
\hline TSI Chl a & 48 & 60 \\
\hline TSI TP & 38 & 51 \\
\hline trophic state & mesotrophy & eutrophy \\
\hline
\end{tabular}

** Final category I-IV (where, I = lake very resistant to catchment's impact and IV = lake not resistant to catchment's impact) and partial scores* were calculated according to the method proposed by Bajkiewicz-Grabowska (1981, 1987) in Dunalska (2010).

*** Trophic state index (summer month, epilimnion waters ) calculated according to Carlson (1977).

and management of the watersheds, it is assumed that the influxes of allochthonous organic matter into both lakes are similar (Chróst and Siuda, 2006). This assumption was confirmed by the evaluation of the lakes' susceptibility to catchment impacts (Dunalska 2010). Although the partial scores of this evaluation differ to some extent, the total result is the same (Table lb): both lakes are moderately resistant to catchment impacts (category II in a four-degree scale). The two lakes differ in trophic state: Lake Mikołajskie is eutrophic, whereas Lake Majcz Wielki is mesotrophic (Table lb). The results of the trophic state evaluation are consistent with the current trophic state estimations previously performed by Chróst and Siuda (2006).

\section{> PHYSICAL AND CHEMICAL ANALYSES}

Samples were taken for physical and chemical analyses from each lake at a site situated over the deepest point of the lake with a Ruttner-type water sampler. Samples were taken once a month in the spring, summer and fall (from the end of April to October) in 2007 and 2008. Both lakes were sampled on the same day. The samples were taken from the upper layer, which included the epilimnion and metalimnion during stratification. The depth of these layers was determined each time when the sampling took place. The sampling depth depended on a current temperature profile (the maximal sampling depth in both lakes reached approximately 10.0-12.0 m). The maximal depth of the epilimnion was $6.0 \mathrm{~m}$ (August 2008) in Lake Majcz Wielki and 7.0 m (August 2008) in Lake Mikołajskie. A total of 28 samples were 
collected in each lake. Oxygen $\left(\mathrm{O}_{2}\right)$ concentration was measured using a $\mathrm{YSI} 58$ dissolved oxygen meter, and water transparency (SD) was determined using a Secchi disc. Electrical conductivity (Cond.) was determined using a DIGI 610 conductivity meter and the $\mathrm{pH}$ of water was measured using a Ross-type Orion $\mathrm{pH}$-meter. Total phosphorus (Tot-P), soluble reactive phosphorus $\left(\mathrm{PO}_{4}-\mathrm{P}\right)$, total nitrogen (Tot-N) and nitrate $\left(\mathrm{NO}_{3}-\mathrm{N}\right)$ were determined using standard methods (Clesceri et al., 1998; Hermanowicz et al., 1999). Subsamples for the chlorophyll a (Chl a) determination were kept cool in the dark until they were returned to the laboratory (within $4 \mathrm{~h}$ ). In the laboratory, they were filtered onto GF/C glass fiber filters and immediately elaborated using the grinding technique and acetone as a solute. The chlorophyll a concentration was measured using a spectrophotometer (Shimadzu UV 1601) with an adjustment for phaeopigments (Clesceri et al., 1998). Subsamples for DOC and TOC determination were collected in dark, polyethylene bottles and were kept cool in the dark until they were returned to the laboratory (within $4 \mathrm{~h}$ ). The carbon content in lake water was determined immediately after transportation. Total organic carbon (TOC) and dissolved organic carbon (DOC) were determined in non-filtered and filtered samples, respectively, using a TOC-500 analyzer (Shimadzu). Samples were acidified to $\mathrm{pH} 2$ with $2 \mathrm{M} \mathrm{HCl}$ and purged with carbon dioxide-free carrier gas for $5 \mathrm{~min}$ at a flow rate of $125 \mathrm{~mL} \cdot \mathrm{min}^{-1}$ to remove inorganic carbon. The particulate organic carbon (POC) concentration was calculated as the difference between total and dissolved carbon concentrations. The quality of the dissolved organic matter was measured using specific ultraviolet absorbance (SUV A), defined as the UV absorbance of a water sample at a given wavelength normalized against DOC concentration. A spectrophotometer (Shimadzu UV-1601PC, Japan) was used to measure the UV absorbance (at $260 \mathrm{~nm}$ ) in the water samples (Fukushima et al., 1996; Zieliński and Górniak, 1999; Weishar et al., 2003; Aoki et al., 2004).

\section{$>$ ZOOPLANKTON}

Zooplankton were collected using a 5-L Patalas sampler, and $30 \mathrm{~L}$ of water were collected each time. Separate samples were taken for the epilimnion and metalimnion. The procedure of sampling depth determination was the same as for physico-chemical samples. Each water layer was sampled at equal intervals (usually 1.0-2.0 m). The samples were concentrated by filtration through a $30-\mu \mathrm{m}$ mesh. Rotifers and planktonic crustaceans were classified by species (except for juvenile copepods) using as references Flössner (1972), Koste (1978), Kiefer and Fryer (1978).

For the abundance analysis, $1-\mathrm{mL}$ subsamples were taken with an automatic pipette (from each sample with a total volume of approximately 30-50 mL) and placed in a SedgewickRafter chamber. About 10 individuals of each species were measured to determine the body length. The individual weights of rotifers were estimated from average lengths, according to Ruttner-Kolisko (Ruttner-Kolisko, 1977) and Ejsmont-Karabin (Ejsmont-Karabin, 1998). The lengths of crustaceans were converted to weights, according to Botrell et al. (1976).

The number of planktonic animals, total biomass ( $\mathrm{B}$ tot) and the biomasses of cladocerans $(\mathrm{B} \mathrm{Cl})$, copepods (B cp) and rotifers $(\mathrm{B} \mathrm{r})$ were estimated. The Crustacea biomass was calculated as the sum of the biomass of cladocerans and copepods. The zooplankton dominance structure was evaluated according to Kasprzak and Niedbała (1981).

\section{STATISTICAL ANALYSIS}

The elaboration of the data set included the following:

- statistical tests of significance for the differences between the lakes in environmental variables and zooplankton abundance using the paired $t$-test;

- ordination techniques to describe the relationships between the abundance of zooplankton and environmental variables. An indirect multivariate method, DCA, was applied to select the ordination technique. Because the length of the gradient was $<3$ standard 


\section{Table II}

Environmental conditions (mean and standard deviation (SD)) in the studied lakes (MW-Lake Majcz Wielki; M-Lake Mikołajskie) and the significance of differences (paired t-test; differences significant at $\alpha=0.05)$ between the average values of variables. Abbreviations: Tot- $P,{P O_{4}-P=t o t a l}-P$ and soluble reactive phosphorus, respectively; Tot- $N=$ total nitrogen, $\mathrm{NO}_{3}-N=$ nitrates, respectively; TOC, DOC, $P O C=$ total, dissolved and particulate organic carbon, respectively; SUVA = value of absorbance standardized for DOC; Cond. = electrical conductivity, $\mathrm{O}_{2}=$ oxygen; $\mathrm{SD}=$ Secchi disc visibility and Chl $a=$ chlorophyll a.

\begin{tabular}{|c|c|c|c|}
\hline & \multicolumn{2}{|c|}{ Mean \pm SD } & \multirow{2}{*}{$\begin{array}{c}\text { The significance } \\
\text { of differences }\end{array}$} \\
\hline & MW & M & \\
\hline Tot-P $\left[\mathrm{mg} \cdot \mathrm{L}^{-1}\right]$ & $0.10 \pm 0.05$ & $0.15 \pm 0.10$ & $t=-3.26 ; P=0.003$ \\
\hline $\mathrm{PO}_{4}-\mathrm{P}\left[\mathrm{mg} \cdot \mathrm{L}^{-1}\right]$ & $0.01 \pm 0.01$ & $0.05 \pm 0.07$ & $t=-2.66 ; P=0.01$ \\
\hline Tot-N [mg $\left.\cdot \mathrm{L}^{-1}\right]$ & $1.2 \pm 0.6$ & $1.3 \pm 0.3$ & n.s. ${ }^{*}$ \\
\hline $\mathrm{NO}_{3}-\mathrm{N}\left[\mathrm{mg} \cdot \mathrm{L}^{-1}\right]$ & $0.3 \pm 0.1$ & $0.3 \pm 0.2$ & n.s. \\
\hline TOC $\left[\mathrm{mg} \cdot \mathrm{L}^{-1}\right]$ & $7.8 \pm 0.8$ & $9.5 \pm 1.4$ & $t=-9.87 ; P=0.0000$ \\
\hline $\mathrm{DOC}\left[\mathrm{mg} \cdot \mathrm{L}^{-1}\right]$ & $6.0 \pm 0.7$ & $8.2 \pm 1.0$ & $t=-11.48 ; P=0.0000$ \\
\hline $\mathrm{POC}\left[\mathrm{mg} \cdot \mathrm{L}^{-1}\right]$ & $1.0 \pm 0.6$ & $1.5 \pm 0.7$ & $t=-2.69 ; P=0.01$ \\
\hline SUV A $\left[\mathrm{cm}^{-1}(\mathrm{gC})^{-1} \cdot \mathrm{L}^{-1}\right]$ & $22.4 \pm 1.98$ & $23.9 \pm 1.81$ & n.s. \\
\hline Cond. $\left[\mu \mathrm{S} \cdot \mathrm{cm}^{-2}\right]$ & $360 \pm 16.4$ & $378 \pm 23.1$ & $t=-5.09 ; P=0.001$ \\
\hline $\mathrm{pH}$ & $7.9 \pm 0.4$ & $8.0 \pm 0.6$ & n.s. \\
\hline $\mathrm{O}_{2}\left[\mathrm{mg} \cdot \mathrm{L}^{-1}\right]$ & $7.5 \pm 3.3$ & $6.8 \pm 5.0$ & n.s. \\
\hline SD [m] & $3.3 \pm 0.6$ & $2.1 \pm 0.5$ & $t=5.28 ; P=0.0005$ \\
\hline Chl a $\left[\mu \mathrm{g} \cdot \mathrm{L}^{-1}\right]$ & $10.6 \pm 11.7$ & $17.1 \pm 16.7$ & $t=-2.32 ; P=0.01$ \\
\hline
\end{tabular}

${ }^{*}$ Differences between the two means not significant (n.s.).

deviations, redundancy analysis (RDA) was used to explore the relationship between the abundance of zooplankton communities and the physical and chemical variables (ter Braak and Šmilauer, 2002). In the case of variables differing from a normal distribution, an approximately normal distribution with a $\operatorname{Ln}(x+a)$ transformation was obtained;

- determination of the relationships between selected environmental variables in each lake using Spearman's rank correlations.

The data were statistically analyzed using STATISTICA 9.0. The Canoco 4.5 for Windows/CanoDraw software was used for ordination.

\section{RESULTS}

The lakes in which we investigated the response of plankton organisms to the dynamics of qualitative and quantitative changes in organic carbon differed in their physical and chemical data (Table II). Among the parameters considered, both water bodies particularly differed in the average organic carbon concentrations. The TOC concentration was significantly higher in the eutrophic lake than in the mesotrophic lake ( $t$-test; $P<0.05)$. The same direction of variability was detected for DOC ( $t$-test; $P<0.05)$ and POC ( $t$-test; $P<0.05)$ concentrations. We found that the proportion of DOC in the TOC pool increased together with the trophic state, which was confirmed by the significant correlation between TOC and DOC $(r=0.8$; $P<0.05)$ in the eutrophic lake. In the mesotrophic lake, this correlation was weaker $(r=0.58$; $P<0.05)$. A significant relationship was also found between total and particulate organic carbon $(P<0.05)$ concentrations. In this case, the values of the correlation coefficients were similar for the eutrophic and mesotrophic lakes ( $r=0.64$ and $r=0.60$, respectively) (Table III). The two lakes differed in Tot- $\mathrm{P}$ and $\mathrm{PO}_{4}-\mathrm{P}$ concentrations, which was confirmed by the $t$-test $(P<0.05)$. Higher nutrient availability in a lake of higher fertility results in more intensive phytoplankton development, which was confirmed by the difference in the average concentration of Chl a ( $t$-test; $P<0.05)$ between the lakes (Table II).

In the eutrophic lake, a positive correlation was found between the concentration of $\mathrm{Chl}$ a and TOC $(r=0.76 ; P<0.05)$, POC $(r=0.62 ; P<0.05)$ and DOC $(r=0.52 ; P<0.05)$; this was 


\section{Table III}

Spearman correlation coefficients $(P<0.05)$ determining (a) the contribution of dissolved and particulate organic carbon (DOC, POC) to the variance of organic carbon (TOC) and (b) the relationship between chlorophyll a concentration (Chl a) and organic carbon content (TOC, DOC, POC) in the mesotrophic Lake Majcz Wielki (MW) and the eutrophic Lake Mikołajskie (M).

\begin{tabular}{|l|c|c|c|c|c|}
\hline \multicolumn{3}{|c|}{ (a) TOC } & \multicolumn{3}{c|}{ (b) Chl a } \\
\hline Lake & DOC & POC & TOC & DOC & POC \\
\hline MW & 0.58 & 0.60 & n.s. $^{*}$ & n.s. & n.s. \\
\hline M & 0.80 & 0.64 & 0.76 & 0.52 & 0.62 \\
\hline
\end{tabular}

${ }^{*}$ Relationship not significant (n.s.).

not observed in the mesotrophic lake (Table III). Some other physical and chemical variables were also significantly different. The average Secchi disc visibility (SD) was higher in the water body with the lower trophic state $(t$-test; $P<0.05)$, whereas electrical conductivity was higher in the eutrophic lake $(t$-test; $P<0.05)$. No significant differences $(P>0.05)$ were detected in the remaining variables (Table II).

Environmental conditions in the lakes affected the biocoenosis. In the mesotrophic lake, higher zooplankton species richness was found than in the eutrophic lake (65 species, of which 46 were Rotifera, 12 Cladocera and 7 Copepoda) along with more even contributions of particular taxa to the total biomass than in the eutrophic lake. Among the rotifers, Asplanchna priodonta, Keratella cochlearis, Keratella quadrata, Polyarthra dolichoptera and Synchaeta pectinata were eudominants. Among the copepods, large-bodied species were most abundant such as Eudiaptomus gracilis and Eudiaptomus graciloides. Among cladocerans, Daphnia cucullata and Daphnia cristata were prominent. The total number of species was lower in the eutrophic lake (52). The zooplankton biocoenosis was dominated by planktonic rotifers (34 species), in which Asplanchna priodonta, Polyarthra dolichoptera and Synchaeta pectinata were predominant in terms of biomass. Copepoda (8 species) were mainly represented by Mesocyclops leuckarti, Thermocyclops oithonoides, E. graciloides, whereas Cladocera (10 species) were represented by the two eudominants Bosmina coregoni ssp. thersites and D. cucullata (Table IV).

The taxonomic composition of zooplankton was differentiated between the lakes to a larger extent than abundance data. The average biomass of Copepoda was the exception because it was significantly higher ( $t$-test, $P<0.05$ ) in the mesotrophic lake, where species with higher individual weight and larger body size predominated (Table V).

The tests of significance of the differences between the average values of the physical and chemical parameters demonstrated that the examined lakes differed with respect to most variables associated with trophic state and the quality and quantity of organic carbon in their waters. RDA analyses were performed to specify the relationships between the abundance of the zooplankton taxonomic groups and environmental variables. Clear differences between the lakes were found. In the mesotrophic lake, the redundancy analysis results suggested a possible limiting effect of phytoplankton on zooplankton (Figure 1a). This limiting effect was indicated by the negative relationships between the $\mathrm{Chl}$ a concentration and biomass of cladocerans as well as the biomass of rotifers and total zooplankton biomass. Phytoplankton and zooplankton were negatively correlated, mainly in summer (Figure 1b). There was less of a negative impact recorded for POC, which mostly affected the biomass of rotifers, mainly in summer (Figure 1a, 1b). An opposite response by zooplankton was recorded when the influence of DOC was considered (Figure 1a). This form of organic carbon was positively correlated with total zooplankton biomass and cladoceran biomass. The impact of DOC on the biomass of crustaceans and copepods was less apparent. The direction of these correlations suggests DOC utilization by zooplankton. A relatively strong positive relationship was detected between Tot- $\mathrm{N}$ and total zooplankton number. Other environmental variables had a weaker (dissolved oxygen concentration and $\mathrm{pH}$ ) or negligible effect on zooplankton. 


\section{Table IV}

Dominant taxa and the domination structure (according to biomass) of Rotifera and Crustacea in Lake Majcz Wielki (MW) and Lake Mikołajskie (M).

\begin{tabular}{|l|c|c|}
\cline { 2 - 3 } \multicolumn{1}{l|}{ Rotifera } & MW & M \\
Asplanchna priodonta & & \\
Conochilus hippocrepis & ++ & +++ \\
Conochilus unicornis & + & \\
Filinia terminalis & ++ & + \\
Kelicotia longispina & + & \\
Keratella cochlearis & ++ & + \\
Keratella quadrata & +++ & ++ \\
Polyarthra dolichoptera & +++ & ++ \\
Polyarthra major & +++ & +++ \\
Synchaeta pectinata & ++ & \\
Trichocerca similis & +++ & +++ \\
\hline Crustacea & & + \\
Bosmina coregoni & & \\
Bosmina coregoni ssp. thersites & + & \\
Bosmina longirostris & ++ & +++ \\
Ceriodaphnia quadrangula & ++ & \\
Chydorus sphaericus & ++ & \\
Cyclops vicinus & ++ & + \\
Daphnia cucullata & +++ & +++ \\
Daphnia cristata & +++ & ++ \\
Daphnia longispina & & + \\
Diaphanosoma brachyurum & ++ & \\
Eudiaptomus gracilis & +++ & \\
Eudiaptomus graciloides & +++ & ++ \\
Mesocyclops leuckarti & + & +++ \\
Thermocyclops oithonoides & ++ & +++ \\
copepodites Calanoida & ++ & +++ \\
copepodites Cyclopoida & ++ & +++ \\
nauplii & +++ & + \\
\hline
\end{tabular}

The level of dominance is indicated as follows: +++ eudominant $(>10 \%) ;++$ dominant $(5.1-10 \%)$; + subdominant $(2.1-5.0 \%)$.

\section{Table $V$}

Mean zooplankton density [indiv. $\mathrm{L}^{-1}$ ] and biomass [mg. $\left.\mathrm{L}^{-1}\right]$, standard deviation (SD) and significance of differences between the lakes (paired t-test; differences significant at $\alpha=0.05$ ).

\begin{tabular}{|l|c|c|c|}
\cline { 2 - 3 } \multicolumn{1}{c|}{} & \multicolumn{2}{c|}{ Mean and standard deviation } & \multirow{2}{*}{$\begin{array}{c}\text { Significance } \\
\text { of differences }\end{array}$} \\
\cline { 2 - 3 } \multicolumn{1}{c|}{ RWW } & M & n.s. ${ }^{*}$ \\
\hline Cladocera density & $391.6 \pm 447.8$ & $402,3 \pm 416,3$ & n.s. \\
\hline Copepoda density & $46.6 \pm 33.8$ & $35.6 \pm 28.6$ & n.s. \\
\hline Rotifera biomass & $104.2 \pm 68.3$ & $74.0 \pm 41.1$ & n.s. \\
\hline Cladocera biomass & $0.27 \pm 0.34$ & $0.35 \pm 0.51$ & n.s. \\
\hline Copepoda biomass & $1.05 \pm 0.89$ & $1.04 \pm 1.06$ & $t=-2.97 ; P=0.03$ \\
\hline
\end{tabular}

* Differences between the two means not significant (n.s.)

MW-Lake Majcz Wielki

M-Lake Mikołajskie 


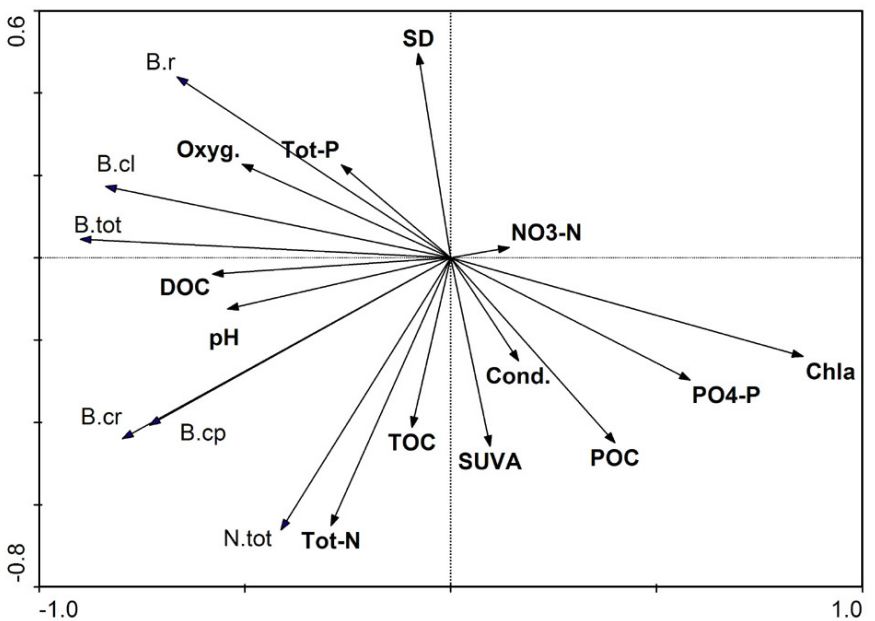

(a)

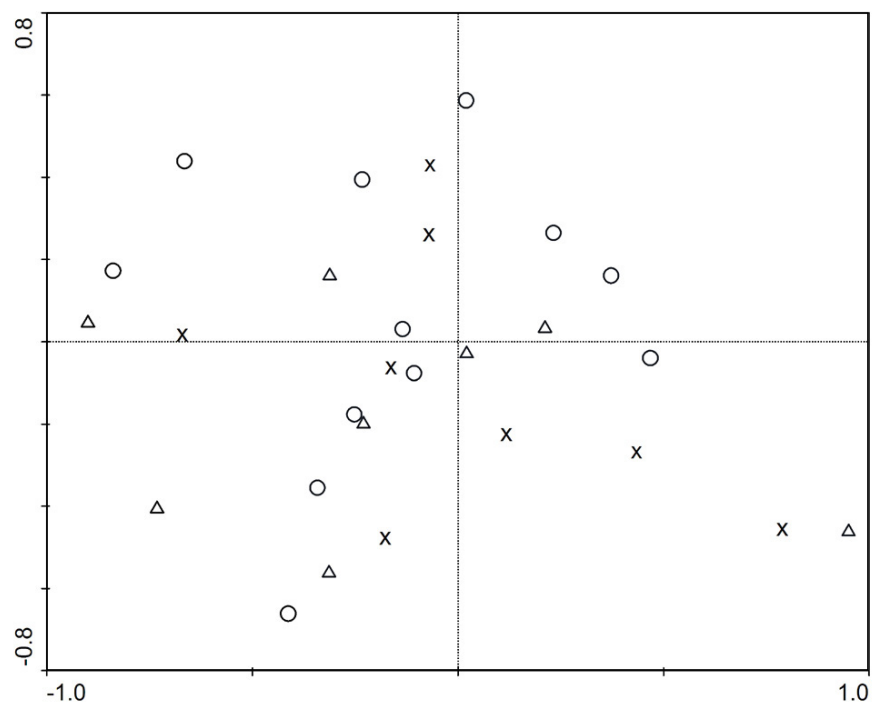

(b)

\section{Figure 1}

(a) Redundancy Analysis (RDA) biplot for the mesotrophic lake showing the zooplankton community and environmental variables. Abbreviations: $B$ tot, $B c p, B c l, B r=$ total zooplankton, Copepoda, Cladocera and Rotifera biomasses, respectively; $N$ tot = total zooplankton number; $\mathrm{Chl} a=$ chlorophyll a, TOC, DOC, $P O C=$ total, dissolved and particulate organic carbon, respectively; Tot- $P, P_{4}-P=$ total and soluble reactive phosphorus, respectively; Tot- $\mathrm{N}, \mathrm{NO}_{3}-\mathrm{N}=$ total nitrogen and nitrate, respectively; $\mathrm{O}_{2}$ = oxygen; Cond. = electrical conductivity, $S D=$ Secchi disc visibility, and SUVA = the absorbance value standardized for DOC. (b) Redundancy Analysis (RDA) for the mesotrophic lake showing samples collected in the studied months: triangles - spring samples, circles - summer samples, $x$-mark - fall samples.

The RDA biplot of zooplankton and environmental variables based on the first two axes explained $72.3 \%$ of the variance in the zooplankton data and $84.3 \%$ of the variance in the correlations and the class means of zooplankton with respect to environmental variables. A Monte Carlo permutation test showed the significance of three variables: $\mathrm{Chl}$ a $(F=12.72$; $p=0.002)$, DOC $(F=1.99 ; p=0.04)$ and Tot-N $(F=2.95 ; p=0.03)$.

In the eutrophic lake, the RDA biplot indicated a distinct positive influence of POC concentrations on total zooplankton biomass; crustacean biomass in particular (Figure 2a). This impact was not so evident in the case of zooplankton taxonomic groups, i.e. the biomass of copepods and cladocerans. These correlations suggest the possible grazing of zooplankton 


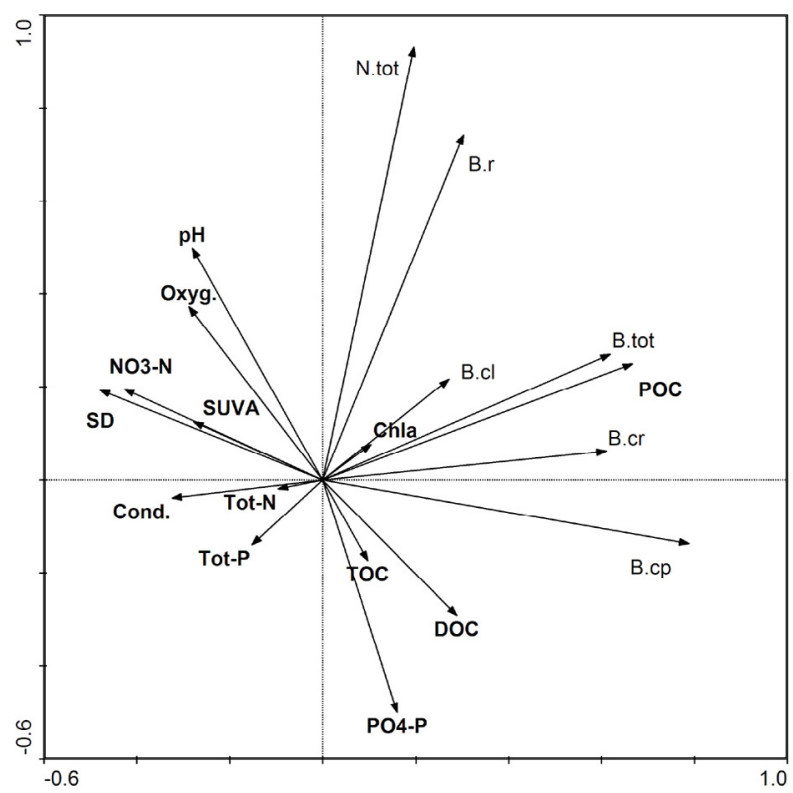

(a)

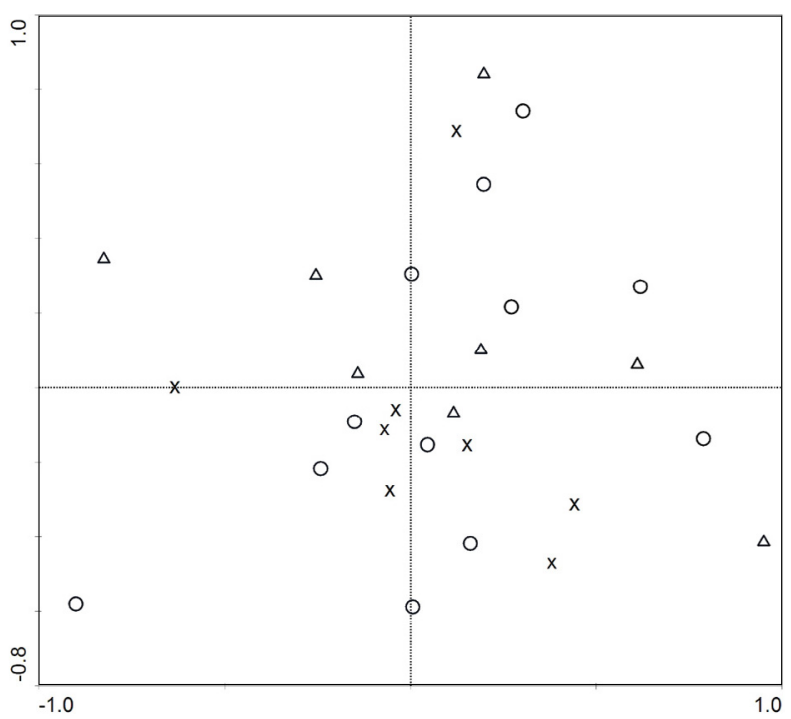

(b)

\section{Figure 2}

(a) Redundancy Analysis (RDA) biplot for the eutrophic lake showing the zooplankton community and environmental variables. Abbreviations: $B$ tot, $B \mathrm{cp}, \mathrm{B} \mathrm{cl}, \mathrm{B} r=$ total zooplankton, Copepoda, Cladocera and Rotifera biomasses, respectively; $N$ tot = total zooplankton number; $\mathrm{Chl}$ a = chlorophyll a, TOC, $D O C, P O C=$ total, dissolved and particulate organic carbon, respectively; Tot $-P, P O_{4}-P=$ total and soluble reactive phosphorus, respectively; Tot- $\mathrm{N}, \mathrm{NO}_{3}-\mathrm{N}=$ total nitrogen and nitrate, respectively; $\mathrm{O}_{2}=$ oxygen; Cond. = electrical conductivity, $S D=$ Secchi disc visibility, and SUVA = the absorbance value standardized for DOC. (b) Redundancy Analysis (RDA) for the eutrophic lake showing samples collected in the studied months: triangles - spring samples, circles - summer samples, $x$-mark - fall samples.

on suspended matter. There was much less of a positive impact detected in the case of chlorophyll a concentrations, which mostly affected the biomass of cladocerans (in spring and summer - Figure 2a, 2b). POC influenced total zooplankton biomass and the biomass of crustaceans, mainly in spring and summer (Figure $2 \mathrm{~b}$ ).

A positive correlation between DOC concentrations and copepod biomass was found (Figure 2a). Such a relationship may suggest indirect utilization of this form of organic carbon. For other environmental variables, negative correlations between water transparency and the 
biomass of copepods, as well as nitrate concentrations and the biomass of copepods, were recorded.

In this lake, the RDA biplot of zooplankton and environmental variables based on the first two axes explained $61.0 \%$ of the variance in the zooplankton data and $87.9 \%$ of the variance in the correlations and the class means of zooplankton with respect to environmental variables. However, variables that significantly $(p<0.05$, Monte Carlo) explained the variance in zooplankton community abundance included POC $(F=4.04 ; p=0.02)$, DOC $(F=2.02 ; p=0.03)$, water transparency $(F=1.91 ; p=0.04)$ and $\mathrm{PO}_{4}-\mathrm{P}(F=2.40 ; p=0.03)$.

\section{DISCUSSION}

The studied lakes differ in environmental conditions, including the contents of particular forms of organic carbon. The average concentration of DOC did not exceed $10 \mathrm{mg} \cdot \mathrm{L}^{-1}$ in either lake. Therefore, it can be assumed that the metabolism of both lakes is autotrophic (Jansson et al., 2000; Hanson et al., 2003), implying that the increase in organic carbon should be mainly associated with autochthonous sources and that the response of the zooplankton community should be associated with the internal transformations of matter in the water body.

In the mesotrophic lake, the RDA suggested that phytoplankton limited zooplankton growth (cladocerans and rotifers, in particular). This usually occurs in highly eutrophicated lakes in which filamentous blue-green algae prevail, and among which many species are potentially toxic (Hillbricht-Ilkowska and Kajak, 1986). In the examined lake, among the dominants, Cyanoprokaryota were of minor importance in comparison with Baccillariophyceae and Chrysophyceae. In all of these phytoplankton groups, though, there was a predominance of large-sized or colonial species recorded (Jaworska, 2010). Such species can decrease zooplankton feeding efficiency (Kawecka and Eloranta, 1994). The quantity and quality of organic carbon recycled by zooplankton can also be affected. Small-sized algae may be ingested whole by zooplankton and easily digested, and as a result, most of the organic carbon is released as DOC through excretion. Algal food assimilation is much less efficient when zooplankton feed on large species (e.g., colony forms). Additional amounts of DOC are released into the water as a result of feeding on large algae. It mostly originates from "sloppy feeding" or from poorly-digested feces (Richardot et al., 2001). The above could take place in the examined lake. In this way, zooplankton feeding activity could affect the content of autochthonous DOC in the lake water, supporting other common sources, i.e. DOC generated by phytoplankton during photosynthesis (Vadstein et al., 1989) or DOC originating from detritus (Vadstein et al., 1989; Hoppe, 1984). Because of a lack of a significant correlation between the concentrations of chlorophyll a and dissolved organic carbon, zooplankton can become an important source of DOC in the studied lake. To verify this thesis, we correlated total zooplankton number and biomass with DOC concentrations (Spearman's rank correlation). The results are significant though relationships are weak $(r=0.42 ; p<0.05$ and $r=0.48$; $p<0.05$, respectively). In total, herbivorous grazing may result in the recycling of from 10 to $37 \%$ of previously consumed POC (in the form of an algal suspension) that is returned as DOC (Lampert, 1978; Strom et al., 1997). In waters of moderate fertility, the intensity of DOC released by zooplankton may reach the level of supply by phytoplankton (Strom et al., 1997; Olsen et al., 2007).

The total pool of available DOC can be easily assimilated by heterotrophic bacteria and transferred to the zooplankton trophic level, which has been reported in other studies (Olsen et al., 1986; Hygum et al., 1997; Strom et al., 1997). In the examined lake, this pattern of organic carbon flow seems to take place since there are positive correlations between the DOC concentration and zooplankton biomass (the RDA results). Indirect utilization of DOC by crustacean plankton is a commonly known phenomenon. Studies have reported that cladocerans (Jack and Gilbert, 1994) as well as adult cyclopoids (Wiliamson, 1983, Stoecker and Capuzzo, 1990) can feed on heterotrophic nanoflagellates, ciliates and rotifers, which in turn benefit from bacterial secondary production. However, the efficiency of this process should not be high because the results of another study performed in this lake evidenced that the bacterial 
secondary production (with the mean value varying between $50-150 \mu \mathrm{g} \cdot \mathrm{C} \cdot \mathrm{L}^{-1} \cdot \mathrm{h}^{-1}$ ) and the activity of heterotrophic bacteria (bacterial organic carbon demand estimated for this lake was on average $388 \mu \mathrm{g} \cdot \mathrm{C} \cdot \mathrm{L}^{-1} \cdot \mathrm{d}^{-1}$ ) are relatively low (Chróst and Siuda, 2006). Nevertheless, this pathway of organic carbon utilization by planktonic animals could partly compensate for the poor feeding conditions of zooplankton, resulting from poor phytoplankton availability.

In the mesotrophic lake, the POC content limited the biomass of rotifers. It is difficult to explain this effect when the size structure of POC is unknown. The particles of organic matter were probably too large to be ingested by the dominant rotifer species. For instance, $C$. hippocrepis prefers detritus particles smaller than $10 \mu \mathrm{m}$ (Pourriot, 1977).

Greater contents of all carbon forms are observed in the eutrophic lake than in the mesotrophic lake, and this carbon content is affected by a growing biomass of phytoplankton. This result is confirmed by the observation of a significantly higher concentration of Chl a and its significant proportion in the total and particulate organic carbon concentrations. Phytoplankton has become an important autochthonous source of DOC in the eutrophic lake, as indicated by the positive correlation between the $\mathrm{Chl}$ a and dissolved organic carbon concentrations (not detected in the mesotrophic lake).

The supply of DOC to the water by phytoplankton may be particularly intensive during algal blooms, which has been previously documented. During intensive photosynthesis, up to $60 \%$ of the assimilated carbon may be extracellularly released into the water as dissolved organic carbon (Chróst, 1984; Vadstein et al., 1989). Additional amounts are generated during the decomposition of algal cells, e.g., following the cessation of algal blooming (Sønddergaard et al., 2001). When lakes are mainly supplied with autochthonous sources of DOC, the availability of nutrients in a system influences the amount of carbon assimilated and released by algae, which materially determines its total content in the water (Obernosterer and Herndl, 1995). This mechanism may have contributed to the increase in DOC content in the TOC pool in the eutrophic lake, which is highlighted by a higher (in comparison with water of lower trophic state) value of the correlation coefficient between these variables.

The growing importance of phytoplankton supplying water with DOC could be limited, to a certain extent, by zooplankton feeding. The examined eutrophic lake contained an abundant population of filter-feeding Daphnia, especially D. cucullata. Productive systems capable of generating and maintaining high levels of POC are usually rich in microphytoplankton and efficiently filtering Cladocera, which are able to eliminate substantial amounts of suspension from the water (Reynolds, 2008 and included references). This can explain the positive relationship between the chlorophyll a concentration and the biomass of cladocerans demonstrated by the redundancy analysis. However, it seems that most of the phytoplankton primary production remains unaffected (no relationship with other zooplankton groups).

In eutrophic lakes, excessive algal production is turned into detritus, which becomes increasingly important in zooplankton feeding (Hillbricht-llkowska and Kajak, 1986). This fact can explain the strong, positive correlations between POC concentrations and zooplankton revealed by RDA (not found in the mesotrophic lake). The summarized effect of zooplankton trophic activity limited the total pool of POC, but the contribution of particular zooplankton groups differed. The position of cladocerans in the ordination diagram (i.e. in the vicinity of the $\mathrm{Chl}$ a vector) suggests that this zooplankton group mainly affects the concentration of POC by elimination of algal suspension.

Copepods largely contribute to the elimination of total POC from the water but they seem to benefit mostly from food sources other than phytoplankton (no relationship with the $\mathrm{Chl}$ a concentration in the ordination diagram). The excessive organic matter may be utilized in a detritus food chain in which detritus, together with colonizing bacteria, may constitute a food source for small zooplankters, which subsequently become prey for predatory Cyclopoida (Legendre and Rivkin, 2008). In this way, copepods may indirectly utilize particulate organic matter, which explains the correlation observed in the eutrophic lake. Copepoda are the only zooplankton group which can also benefit from increased (in comparison with the mesotrophic lake) concentrations of DOC in lake water, as suggested by the RDA results. The efficiency of this heterotrophic organic carbon 
pathway (bacteria-microzooplankton-copepods) should be high (contrary to the mesotrophic lake). Studies on the microbial community estimated bacterial production in this lake at 200-400 $\mu \mathrm{g} \cdot \mathrm{C} \cdot \mathrm{L}^{-1} \cdot \mathrm{h}^{-1}$ (Chróst and Siuda, 2006; Górniak, 2010). Moreover, high protozoan grazing activity on microorganisms, i.e. $\sim 10 \times 10^{5}$ bacteria $\mathrm{m} \cdot \mathrm{L}^{-1} \cdot \mathrm{h}^{-1}$, was reported by Chróst and Siuda (2006).

This dual-mode feeding pattern performed by Copepoda within the eutrophic lake is confirmed by the position of the copepod biomass on the ordination diagram, i.e. between the $\mathrm{POC}$ and DOC vectors. It appears that copepods play a crucial role in the cycling of matter in waters with high trophic states.

Furthermore, our findings indicate that copepods are the only group of planktonic animals that reacted both quantitatively and functionally to changes in the trophic state in the lakes studied here. The eutrophic lake was characterized by a significantly lower biomass of copepods and a shift in dominance structure from large, herbivorous forms (predominating in the mesotrophic lake) towards an increasing proportion of smaller, predatory species. This tendency is consistent with the general concept that structural and functional changes occur in aquatic ecosystems during lake eutrophication. The major rule associated with this concept is that decreasing efficiency in the planktonic food chain (algae and their grazers) is accompanied by increasing efficiency in the consumer chain (predator-prey system), and a decrease in the body size of the species in the zooplankton community (Hillbricht-Ilkowska and Kajak, 1986).

Recent studies have reported similar observations. Olsen et al. (2007) reported that supplying a system with nutrients increases the abundance of food resources for the zooplankton, with a simultaneous decrease in the efficiency of food assimilation and a reduction of energy transfer on the pathway that leads directly from the producers. Under these conditions, the heterotrophic flow (microzooplankton - copepods) increases, allocating carbon to a higher trophic level.

In conclusion, the present study and analyzed references indicate that the trophic state and the associated level of organic carbon affect the role of zooplankton in organic matter transfer in a lake ecosystem. For POC and DOC concentrations, significant relationships with the zooplankton communities were detected. In the mesotrophic lake, the zooplankton abundance showed the strongest relationship to the following three environmental variables: chlorophyll a, DOC and total nitrogen. DOC positively influenced copepods and cladocerans, which implies indirect utilization of this form of organic carbon by planktonic crustaceans. The present study also suggests that in the mesotrophic system, autotrophic carbon flow may be altered by an unfavorable size structure and composition of a phytoplankton community.

Under eutrophic conditions, a significantly higher content of all forms of organic carbon was found. Variables that significantly influenced zooplankton were POC, DOC, water transparency and soluble reactive phosphorus. The accumulation of excessive organic carbon (both in particulate and dissolved forms) activates a heterotrophic path of organic carbon transfer through the ecosystem, as indicated by the substantial activities of heterotrophic bacteria and protozoan grazing reported in other studies. The zooplankton group that clearly reacts to elevated carbon levels in a system is the Copepoda; these organisms undergo a functional shift from browsing Calanoida (in the mesotrophic lake) to predatory Cyclopoida (in the eutrophic lake) to benefit from increased heterotrophic carbon flow in the eutrophic lake. Cladocerans and copepods can collectively limit POC and DOC concentrations in lake water. This finding may be particularly important when considering lake management and implies that supporting crustacean communities in eutrophic lakes may prevent an increase in the organic carbon level.

\section{REFERENCES}

Aoki S., Fuse Y. and Yamada E., 2004. Determinations of humic substances and other dissolved organic matter and their effects on the increase of COD in Lake Biwa. Anal. Sci., 20, 159-164.

Azam F., Fenchel T., Field J.G., Gray J.S., Meyer-Reil L.A. and Thingstad F., 1983. The ecological role of water column microbes in the sea. Mar. Ecol. Prog. Ser., 10, 257-263. 
Bottrell H.H., Duncan A., Gliwicz Z.M., Grygierek E., Herzig A., Hillbricht-llkowska A., Kurasawa H., Larsson P. and Węgleńska T., 1976. A review of some problems in zooplankton production studies. Norw. J. Zool., 24, 419-456.

Carlson R.E., 1977. A trophic state index of lakes. Limnol. Oceanogr., 22, 361-369.

Chróst R.J., 1984. Use of ${ }^{14} \mathrm{C}$-dissolved organic carbon (RDOC) released by algae as a realistic tracer of heterotrophic activity measurements for aquatic bacteria. Arch. Hydrobiol. Beih. Ergebn. Limnol., 19, 207-214.

Chróst R.J. and Siuda W., 2006. Microbial production, utilization, and enzymatic degradation of organic matter in the upper trophogenic layer in the pelagic zone of lakes along a eutrophication gradient. Limnol. Oceanogr., 51, 749-762.

Clair T.A., Ehrman J., Kaczmarska I., Locke A., Tarasick D.W., Day K.E. and Maillet G., 2001. Will reduced summer UV-B levels affect zooplankton populations of temperate humic and clearwater lakes? Hydrobiologia, 462, 75-89.

Clesceri L.S, Greenberg A.E. and Eaton A.D. (eds.), 1998. Standard methods for the examination of water and wastewater, 20th edn. American Public Health Association, Washington, DC, 1325 p.

Cole J.J., Pace M.L., Carpenter S.R. and Kitchell J.F., 2000. Persistence of net heterotrophy in lakes during nutrient addition and food web manipulations. Limnol. Oceanogr., 45, 1718-1730.

Cole J.J., Carpenter S.R., Kitchell J.F. and Pace M.L., 2002. Pathways of organic C utilization in small lakes: results from a whole-lake 13C addition and coupled model. Limnol. Oceanogr., 47, 1664-1675.

Dunalska J., 2010. Hydrochemistry and trophic status of Lakes Kuc, Majcz Wielki and Mikołajskie. In: Dunalska J. (ed.), Environmental conditions and trophic state of Lakes Kuc, Majcz Wielki and Mikołajskie (Mazurian Lake District), UWM, Olsztyn, 19-37.

Dunalska J.A., 2011. Total organic carbon as a new index for monitoring trophic state in lakes. Oceanol. Hydrobiol. Studies, 40, 112-115.

Dunalska A.J., Górniak D., Jaworska B. and Gaiser E., 2012. Effect of temperature on organic matter transformation in a different ambient nutrient availability. Ecol. Eng., 49, 27-34.

Ejsmont-Karabin J., 1998. Empirical equations for biomass calculation of planktonic rotifers. Pol. Arch. Hydrobiol., 45, 513-522.

Flößner D., 1972. Krebstiere, Crustacea Kiemen- und Blattfüßer, Branchiopoda, Fischläuse, Branchiura, Veb Gustav Fischer, Verlag, Jena 501 p.

Fukushima T., Park J., Imai A. and Matsushiage K., 1996. Dissolved organic carbon in a eutrophic lake; dynamics, biodegrability and origin. Aquat. Sci., 58, 139-157.

Górniak D., 2010. Bacterioplankton and virioplankton in Lakes: Kuc, Majcz Wielki and Mikołajskie. In: Dunalska J. (ed.), Environmental conditions and trophic state of Lakes Kuc, Majcz Wielki and Mikołajskie (Mazurian Lake District), UWM, Olsztyn, 37-54.

Grey J., Jones R.I. and Sleep D., 2001. Seasonal changes in the importance of the source of organic matter to the diet of zooplankton in Loch Ness, as indicated by stable isotope analysis. Limnol. Oceanogr., 46, 505-513.

Hanson P.C., Bade D.L., Carpenter S.R. and Kratz T.K., 2003. Lake metabolism: Relationship with dissolved organic carbon and phosphorus. Limnol. Oceanogr., 48, 1112-1119.

Häder D-P., Kumar H.D., Smith R.C. and Worrest R.C., 2007. Effects of solar UV radiation on aquatic ecosystems and interactions with climate change. Photochem. Photobiol. Sci., 6, 267-285.

Hermanowicz W., Dojlido J., Zerbe J., Dożańska W. and Koziorowski B., 1999. Physico-chemical analyses of water and wastewater, Arkady, Warszawa, 555 p.

Hillbricht-Ilkowska A. and Kajak Z., 1986. Parameters and indices useful in monitoring of functional and structural changes in lake ecosystems during the process of their eutrophication. In: HillbrichtIlkowska A. (ed.), Monitoring of lake ecosystems, Ossolineum, Wrocław, 23-45.

Hitchcock J., Mitrovic S.M., Kobayashi T. and Westhorpe D.P., 2010. Responses of estuarine bacterioplankton, phytoplankton and zooplankton to dissolved organic carbon (DOC) and inorganic nutrient additions. Estuaries Coasts, 33, 78-91.

Hoppe H.G., 1984. Attachment of bacteria: advantage or disadvantages for survival in the aquatic environment. In: Marshall K.C. (ed.), Microbial adhesion and aggregation, Dahlem Konferenzen, Springer-Verlag, Berlin, 283-302. 
Hygum B.H., Petersen J.W. and Søndergaard M., 1997. Dissolved organic carbon release by zooplankton grazing activity-a high-quality substrate pool for bacteria. J. Plankton Res., 19, 97-111.

Jack L.D., Gilbert J.J., 1997. Effects of metazoan predators on ciliates in freshwater plankton communities. J. Eukaryot. Microbiol., 44, 194-199.

Jansson M., Bergström A.K., Blomqvist A., Isaksson A. and Jonsson A., 1999. Impact of allochthonous organic carbon on microbial food web dynamics and structure in Lake Örträsket. Arch. Hydrobiol., 144, 409-428.

Jansson M., Bergström A.K., Blomqvist A. and Drakare S., 2000. Allochthonous organic carbon and phytoplankton/bacterioplankton production relationships in lakes. Ecology, 81, 3250-3255.

Jaworska B., 2010. Phytoplankton of Lakes Kuc, Majcz Wielki and Mikołajskie. In: Dunalska J. (ed.), Environmental conditions and trophic state of Lakes Kuc, Majcz Wielki and Mikołajskie (Mazurian Lake District), UWM, Olsztyn, 55-72.

Karlsson J., Jonsson A., Meili M. and Jansson M., 2003. Control of zooplankton dependence on allochthonous organic carbon in humic and clear-water lakes in northern Sweden. Limnol. Oceanogr. , 48, 269-276.

Kasprzak K. and Niedbała W., 1981. Biocenotic indices in quantitative study. In: Górny M. and Grüm L. (eds.), Methods applied in soil zoology, PWN, Warsaw, 397-416.

Kawecka B. and Eloranta P.V., 1994. The outline of algae ecology in freshwater and terrestrial environments. PWN Scientific Publishers, Warsaw, 252 p.

Kiefer F., Fryer G., 1978. Das zooplankton der Binnengewässer, Teil 2, E. Schweizerbart' sche Verlagsbuchhandlung, Stuttgart, $380 \mathrm{p}$.

Koste W., 1978. Rotatoria: Die Radertiere Mitteleuropas. V: 1+2, Gebruder Borntraeger, BerlinSttuttgart, I text band, $600 \mathrm{p}$.

Lampert W., 1978. Release of dissolved organic carbon by grazing zooplankton. Limnol. Oceanogr., 23 , 831-834.

de, Lange H., Morris D.P. and Williamson C.E., 2003. Solar ultraviolet photodegradation of DOC may stimulate freshwater food webs. J. Plankton Res., 25, 111-117.

Leech D.M., Williamson C.E., Moeller R.E. and Hargreaves B.R., 2005. Effects of ultraviolet radiation on the seasonal vertical distribution of zooplankton: a database analysis. Arch. Hydrobiol., 162, 445-464.

Legendre L. and Rivkin R.B., 2008. Planktonic food webs: microbial hub approach. Mar. Ecol. Prog. Ser., 365, 289-309.

Obernosterer I. and Herndl G.J., 1995. Phytoplankton extracellular release and bacterial growth: dependence on the inorganic N:P ratio. Mar. Ecol. Prog. Ser., 116, 247-257.

Olsen Y., Vårum K.M. and Jensen A., 1986. Some characteristics of the carbon compounds released by Daphnia. J. Plankton Res., 8, 505-517.

Olsen Y., Andersen T., Gismervik I. and Vadstein O., 2007. Protozoan and metazoan zooplanktonmediated carbon flows in nutrient-enriched coastal planktonic communities. Mar. Ecol. Prog. Ser., 331, 67-83.

Park J., Aizaki M., Fukushima T. and Otsuki A., 1997. Production of labile and refractory dissolved organic carbon by zooplankton excretion: an experimental study using large outdoor continuous flow-through ponds. Can. J. Fish. Aquat. Sci., 54, 434-443.

Perez-Fuentetaja A., Dillon P.J., Yan N.D. and McQueen D.J., 1999. Significance of dissolved organic carbon in the prediction of thermocline depth in small Canadian Shield Lakes. Aquat. Ecol., 33, 127-133.

Pourriot R., 1977. Food and feeding habits of Rotifera. Arch. Hydrobiol. Beih. Ergebn. Limnol., 8, 243-260.

Reynolds C.S., 2008. A changing paradigm of pelagic food webs. Int. Rev. Hydrobiol., 93, 517-531.

Richardot M., Debroas D., Thouvenot A., Sargos D., Berthon L. and Dévaux J., 2001. Influence of cladoceran grazing activity on dissolved organic matter, enzymatic hydrolysis and bacterial growth. J. Plankton Res., 23, 1249-1261.

Ruttner-Kolisko A. 1977. Suggestions for biomass calculations of plankton rotifers. Arch. Hydrobiol. Beih. Ergebn. Limnol., 8, 71-76.

Salonen K. and Hammar T., 1986. On the importance of dissolved organic carbon matter in the nutrition of zooplankton in some lake waters. Oecologia, 68, 246-253. 
Sønddergaard M., Borch N.H. and Reiman B., 2001. Dynamics of biodegradable DOC produced by freshwater plankton communities. Aquat. Microb. Ecol., 23, 73-83.

Stoeckner D.K. and Capuzzo J.M., 1990. Predation on protozoa: its importance to zooplankton. J. Plankton Res., 12, 891-908.

Strom S., Benner R., Ziegler S. and Dagg M.J., 1997. Planktonic grazers are a potentially important source of marine dissolved organic carbon. Limnol. Oceanogr., 42, 1364-1374.

Ter Braak CJF., Šmilauer P., 2002. CANOCO Reference Manual and User's Guide to Canoco for Windows: Software for Canonical Community Ordination (version 4.5). Microcomputer Power, Ithaca, NY, USA, $500 \mathrm{p}$.

Tranvik L.J., 1992. Allochthonous organic matter as an energy source for pelagic bacteria and the concept of the microbial loop. Hydrobiologia, 229, 107-114.

Vadstein O., Harkjerr B.O. and Jansen A., 1989. Cycling of organic carbon in the photic zone of an eutrophic lake with special reference to heterotrophic bacteria. Limnol. Oceanogr., 34, 840-855.

Weishar J.L., Aiken G.R., Bergamaschi B.A., Fram M.S., Fuji R. and Mopper K., 2003. Evaluation of specific absorbance as an indicator of the chemical composition and reactivity of dissolved organic carbon. Environ. Sci. Technol., 37, 4702-4708.

Wetzel R.G., 1983. Limnology. 2nd edn., Saunders, Philadelphia, 767 p.

Wiliamson C.E., 1983. Invertebrate predation on planktonic rotifers. Hydrobiologia, 104, 385-396.

Zieliński P. and Górniak A., 1999. Examination of dissolved organic carbon in natural waters. Aparat. Bad. Dyd., 3, 37-45. 